\title{
The Structural Transformations of Sundanese Wayang Golek Performance
}

\author{
Wawan Gunawan (Corresponding author) \\ Faculty of Humanities, Universitas Padjadjaran, Jalan Raya Bandung-Sumedang \\ Km.21 Jatinangor, Bandung, Indonesia \\ E-mail: dalangwawanajen@yahoo.com
}

Dadang Suganda

Faculty of Humanities, Universitas Padjadjaran, Jalan Raya Bandung-Sumedang

Km.21 Jatinangor, Bandung, Indonesia

Reiza D. Dienaputra

Faculty of Humanities, Universitas Padjadjaran, Jalan Raya Bandung-Sumedang

Km.21 Jatinangor, Bandung, Indonesia

Arthur S. Nalan

Sekolah Tinggi Seni Indonesia

Jalan Buah Batu 212 Bandung, Indonesia

Received: April 2, 2015 Accepted: August 22, 2015 Published: June 24, 2016

doi:10.5296/ijch.v3i1.7364 URL: http://dx.doi.org/10.5296/ijch.v3i1.7364

\begin{abstract}
The Sundanese wayang golek performance has transformed over the years. The transformations happen not only in art elements but also in various elements of its performance including performers, equipments, play, language and literature, act composition, sabet (wayang's movements), time and settings of performance, musical element, stage, and
\end{abstract}


custome players. Regarding these transformations in wayang golek performance, this article tends to study it with the title "The Structural Transformations of Sundanese Wayang Golek Performance". Specifically, this article focuses on the development of Sundanese wayang golek performance art in Karawang. To study it, this research uses qualitative method. Furthermore, its analysis uses social structuration theory approach of Giddens' structuration theory (1984). The transformations of structural elements in wayang golek performance refer not only to additional aspects but also to the aspects of decrement, broadening, constringency, accession or degradation in managing many elements which are part of performance structure of the Sundanese wayang golek. The roles and functions of Sundanese wayang golek performance art include not only as performance art and guidance but also as a creative medium to realize Sundanese wayang golek performance art as a cultural tourism attraction which is beneficial to increase people's welfare.

Keywords: Transformation, Performance structure, Sundanese wayang golek

\section{Introduction}

Wayang (puppet) is one of the people's performance arts which has an established position among other arts in Indonesia's culture. It was not surprising that wayang (The Wayang Puppet Theater of Indonesia) was determined as world "masterpiece" and recognized as world great work by UNESCO in 2003. According to the data of UNESCO, there are 28 types of arts and excellent cultures in the world, and wayang takes the first position as Masterpiece of the Oral and Intangible Heritage of Humanity. This award is the pride of Indonesia as a nation that has established cultures and also it is one of the proofs on the establishment of wayang art conveying great values and meaning of human's life. The arrangement of wayang art as Masterpiece of The Oral and Intangible Heritage of Humanity (2003) by UNESCO must be maintained (Solichin: 2006: 14-15).

Wayang golek, in more common terminology, is a puppet resembling human but in artistic display, played by a dalang (puppeteer) and is accompanied by several musicians and sinden (traditional singer) in a performance. Every civilization has its own history of wayang's development which develops in accordance with transformational dynamic of its people (Suryana, 2002:17). Sundanese wayang golek in the context of Indonesia, is a part of cultural richness of Indonesia, and is a national-historical heritage which shows Indonesia's characteristics, formed based on values and norms respected by Indonesian people for centuries. The following discussion of the article focuses on the Sundanese wayang golek performance in Karawang.

In Karawang, particularly today, there are several models of Sundanese wayang golek performance representing conventional and non-conventional. Conventional is the heir and keeper of wayang golek tradition. Wayang golek as in conventional form can be defined as a tradition or habit which has been passed down from one generation to next one traditionally with its adherence to tetekon (wayang's movements) and pakem (the original stories of the wayang's characters) of puppetry. Currently, there are several conventional Sundanese wayang golek groups including Tjetjep Supriadi, A Darsa Uji Putra, Ujang Muhtar, Entang Sunandar Sunarya, Suparman, Ade Karnawijaya, Yaya Sukarya, Darsa Wibiksana, Ade 
Sunarya, Asep Saehu, Iman Rohendi, Atam, Hengki, Darip, Darwis, and Momo. In addition to the style of conventional wayang golek performance, in Karawang non-conventional style of puppetry also develops. The non-conventional style refers to the wayang performance which does not stick to pakem and tetekon of puppetry as the agreed-basic rules of Sundanese wayang golek performance. The appearance of young generation puppeteers such as Eka Supriadi, Yaya Sukarya, Iman Rohendi, Bubun Subandara, Ratna Juwita, and Dimas (little puppeteer) gives new impressions in Sundanese puppetry especially in Karawang.

Another interesting matter in Karawang is that there are several puppetry styles of Sundanese wayang golek spread in several area in Karawang. It is revealed that there are some puppeteers whose styles resemble famous puppeteers from Bandung including Suparman imitating the puppetry style of Ade Kosasih Sunarya Giri Harya 2 (late), Entang imitating the puppetry style of Asep Sunandar Sunarya Giri Harja 3 (late), Atam imitating the puppetry style of Dede Amung Sutarya (late) Munggul Pawenang Bandung, Ajun imitating the puppetry style of Jamar Media Cianjur, and Omin imitating the puppetry style of Bejo Bogor Meanwhile, the puppetry styles considered as typical Karawang consist of A. Darsa Uji imitating the style of Uji andArta Karawang, Ade Karna and Darsa Wibiksana imitating the puppetry style of Toip, Eka Supriadi and Iman Rohendi imitating the puppetry style of a mixed-style of several famous puppeteers in West Java such as Yaya Sukarya who combines several puppetry styles.

In Karawang, wayang golek has various meanings, forms, and functions. This variety causes many creative explorations which for some people are considered as paradox with the initial values inserted in the wayang golek. A medium is needed to accommodate the variety, the creativity freedom, and also the values articulated in a cultural product of Sundanese wayang golek today in Karawang. The following explanation will describe two examples of the form of wayang golek performance, namely Panca Komara dalang Tjetejep Supriadi and rampak dalang Karawang.

\section{The Sundanese Wayang Golek Performance of Panca Komara Karawang}

The Sundanese wayang golek is defined as a matter of tradition or habit. The same definition goes to the conventional Sundanese wayang golek which is understood as a conventional performance. The following explanation describes the conventional Sundanese wayang golek which has been passed down for generations, traditionally called sapeuting jeput performance or overnight performance. The overnight conventional wayang golek performance (from 20.00 WIB (Western Indonesia Time) to 04.00 mornings) traditionally uses a stage with certain standard and held outdoor, usually in an open field or wide yard. In certain regions, it is called balandongan stage particularly in ceremonial places such as for khitanan (circumcision ceremony), wedding, syukuran (thanksgiving), and ruwatan (a traditional ritual ceremony for keeping away bad lucks). However, in the later development, the conventional wayang golek performance sometimes uses an indoor stage, mainly in big cities. The use of outdoor stage gives more communication space with the audiences and wider social relation (Nalan, 2013 135).

The model of Sundanese wayang golek performance of Panca Komara dalang Tjetjep 
Supriadi represents the area of the heir and keeper of wayang golek tradition as a conventional form defined as a matter of tradition or habit passed down for generations with its traditional adherence to tetekon and pakem of puppetry. The observation result of Sundanese wayang golek performances of Karawang which stick to conventional style includes the performance style which generally remains gugon tuhon (loyal to traditional advices), sticks to pakem and tetekon of puppetry. These matters are revealed in every Sundanese wayang golek performance that always presents the same old patterns conducted repeatedly as a form of adherence to pakem which is a must in the performance. For instance, the performance duration of conventional wayang golek performance is quite long, approximately between 5 to 8 hours or sapeuting jeput (overnight). In prak-prakan ngawayang (performance practice), it always uses long gending-gending tatalu (traditional music in wayang performance) which is followed by gending karatagan ${ }^{1}$. The puppeteer in presenting murwa (introductional music) as the introduction of the performance always delivers murwa text in a mixed-language of Kawi (poet), Javanese, and Sundanese which is very long.

The choice of the play story comes from galur (original story/characters) which is considered loyal to pakem, though it has a fictional story, yet the elements in its performance structure always maintains the conventional patterns. The plot of the story and the scene patterns are delivered the same as the original story without additional or decrement aspects to make the story more interesting, sometimes it is (cawerang) tasteless and (ngayayay) boring. However, despite of it, a puppeteer such as Tjetjep Supriadi prioritizes the story choice and its management which is varied in the language analysis and its puppetry literature. Tjetjep Supriadi plays performance elements, especially the element of puppeteer's voice in antawacana wayang (wayang's dialogue), murwa, nyandra (the description of scenes) and kakawen (traditional song delivered by the puppeteer). These performance elements make the scene structures and the plot of the story clearer and stronger in expressing the plot, theme, and the content of the story which is more dramatic. As explained by Soepandi, that the puppeteers who success in delivering dramatic scenes, one of them is Tjetjep Supriadi of Karawang. Every secene is as if alive, complete, and clear regarding its conflict, which make the audiences impressed and somehow as if involved in the performance (Soepandi, 1984: 74).

The story presentation is more alive and clearer in the characters' description of wayang along with the interesting plots supported good antawacana and its dynamic rhythm conveying profound moral messages. In the terms of wayang golek performance, it is called jero jeung ngeusi (profound and meaningful). The skillful competence of Tjetjep Supriadi in vocal management of his performance along with exploring the essence of the story makes

\footnotetext{
1 Karatagan
}

The name of gending (musical instruments) in wayang golek performance, used in the beginning of the performance before Kawitan (traditional songs), usually called Karatagan Wayang. Started with song after the puppeteer' instruction who plays cempala and kecrek (both are traditional musical instruments). In song term, Karatagan has another definition, that is a march. Several famous marches karatagan pahlawan (heroes karatagan) (see books) and Karatagan Pemuda Indonesia (Indonesian Youth Karatagan) of Mang Koko. (Quoted from Ensiklopedi Sunda. Ajip Rosidi (ed.), 2000: 327). 
his performance alive. He is very capable in processing the story of the play by mastering the technique of the play scenes combined in his performance to make the play more dramatic, such as in the play of Sumur Si Jalatunda, Nurkala Kali Dasa, Bangbang Manggayu Katon, Jaya Geni, Rama Tundung, Sayembara Mantili, Banyu Netra, Dorna Gugur, Sanghyang Wiraga Jati, Satria Pramadewa, Tri Tunggal Jaya Sampurna, and other plays.

\section{The Wayang Golek Performance of Rampak Dalang Karawang}

The wayang golek performance of rampak dalang includes in non-conventional type. It refers to the reality showing that there are wayang golek performances which are not bound to the basic rules of Sundanese wayang golek performance, namely tetekon and pakem of puppetry. There are shift and transformation from conventional wayang golek (Nalan, 2013: 142). In wayang kulit performance, it is called pakeliran padat (short performance). Pertunjukan padat (short performance) also occurs to the non-conventional wayang golek performance. Pertunjukan padat (short performance) refers to the performance duration which only takes a couple of hours (one to three hours). The introduction language of the non-conventional wayang golek performance uses not only Sundanese but also Indonesian and slang of the youth today.

The group of wayang golek rampak dalang of Karawang, initiated by puppeteer Darsa Wibiksana involves 38 puppeteers of Karawang in its performance. Rampak dalang represents the development of Sundanese wayang golek tradition which is more modern in the form of the puppets of wayang golek and its performance is included as non-conventional. The non-conventional wayang golek performance refers to the reality showing that there are Sundanese wayang golek performances which are transformational in the style and performance structures. The style and the performance structures are more flexible in expressing tetekon and pakem of puppetry in more dynamic format. The descriptions above are expected to open new thoughts in viewing the existence of Sundanese wayang golek performance today. In accordance with modern thoughts of self-actualization in the concept of Sundanese culture local wisdoms,"prak geura miindung ka waktu, mibapa ka jaman", meaning that we must always adapt to situation and condition, Suganda proposes that:

"Di era globalisasi ini, kesenian wayang golek Sunda mulai perlahan ditinggalkan. dalam pertunjukan wayang golek Sunda harus ada perubahan agar keberadaan kesenian tradisional ini tetap sesuai dengan perkembangan kebudayaan secara global, kesenian wayang golek Sunda perlu distrukturisasi. Sturkturisasi dilakukan tanpa keluar dari akar tradisi. Salah satu bentuk strukturisasi adalah inovasi. Tanpa inovasi, kesenian wayang golek Sunda akan semakin ditinggalkan. Kesenian wayang golek Sunda membutuhkan perhatian semua pihak, baik pemerintah maupun para pelakunya yaitu seniman dalang. Pemerintah dapat memberikan ruang dan waktu lebih banyak sebagai fasilitas bagi seniman dalang yang terus berinovasi"(Suganda, 2013:).

The Sundanese wayang golek of Karawang in general is one of the people's potential performance arts which is getting excluded. The cultural industrial influence is one of the main factors that demands everything in instant and fast concept. Therefore, the existence of 
traditional art is left behind including the Sundanese wayang golek. This phenomenon occurs as well to young generations who are lacking of their knowledge and love in traditional arts, because today they tend to like modern arts. They think highly of modern arts compared to the traditional arts of their own country. It is indeed ironic that on one hand, the government through culture and art agencies advices young generations to love traditional arts, yet on the other hand the youth tends to ignore it because of the predilection to modern culture.

In addition to the style performance of puppeteer Tjetjep Supriadi of Karawang, the wayang golek performance of rampak 38 dalang of Karawang as a phenomenon existing in the society of Sundanese puppetry of Karawang is a form of transformation of Sundanese wayang golek performance which is different from the Sundanese wayang golek performance in general as a non-conventional form. The existence of non-conventional wayang golek performance causes many 'minor' responses stating that its existence as "a destroyer of Sundanese puppetry tradition" because it violates pakem and tetekon of Sundanese puppetry.

Unlikely, the performance of rampak dalang translates pakem and tetekon of Sundanese puppetry creatively. In fact today, there are many wayang golek performancse of rampak dalang develop in society, as the present writer witnesses in many regions of West Java such as in Bandung (2007), Purwakarta (2009), Pangandaran (2009), Bandung (2010), Bogor (2008, 2009, and 2010), Sukabumi (2011), Tangerang (2012 and 2013), Karawang 38 dalang (2013), Ciamis 16 dalang (2014), and Jakarta 40 dalang (2014). This shows that the existence of wayang golek performance of rampak dalang is developing in society. Thus, in addition to the common wayang golek performance, the wayang golek of rampak dalang becomes important of its existence, roles, and functions in society.

\section{The Transformations of Sundanese Wayang Golek Performance in Karawang}

In analyzing the wayang golek performances of Panca Komara and rampak dalang, there are 12 elements of tetekon and pakem of puppetry in Sundanese culture which become the basic rules of Sundanese wayang golek performance. These elements are structural comparation elements of both wayang golek performances. The elements include Antawacana (wayang's dialogue), awicarita (story play), amardibasa (introduction language), sabet (wayang's movements), amardawalagu (musical element), paramakawi (mastering Kawi language), kawi radya (mastering kakawen raja and nyandra), paramasastra (mastering the language of literature puppetry), renggep (serious and expressive), enges (giving impression), banyol (humor), and tutug (complete) (Salmun, 1961: 188-199). These twelve elements are analyzed in both models of wayang golek performance. Regarding the structural elements of wayang golek performance, the analysis focuses on 10 elements, namely 1) Performer, 2) Equipments, 3) Story, 4) Languge and Literature, 5) Scenes Arrangement, 6) Sabet, 7) Time and Settings of Performance, 8) Musical Element, 9) Stage Arrangement, and 10) Costume Players. Each of the elements certainly has its own operational-structural elements and they can be further analyzed in details (Suganda, 2013). Those elements are categorized into three categories as proposed by Sumarjo (2014), namely Wiraga, Wirahma, and Wirasa. It is also explained by Djelantik (1990:14).

"bahwa kesenian itu pun memiliki unsur-unsur paling tidak ada tiga unsur penting 
yang dapat dikenali dalam setiap karya seni atau bentuk kesenian yaitu (1) wujud (appearance), (2) bobot (content), dan (3) penampilan atau penyajian (presentation)".

The research on structural transformations of Sundanese wayang golek performance, Case Study of Wayang Golek Panca Komara and Wayang Golek Rampak Dalang in Karawang, uses a qualitative method. This method describes the field data as a description of wayang golek performance dynamics of Panca Komara and rampak dalang.

A reconstruction happens when an old postulate is considered to be inapplicable in accordance with social dynamics (Giddens: 2010). In addition to reconstruction, there are also decomposition, renovation, revitalization, refunctionalization, improvisation with various decorations, along with new values touch and breath. Generally, a performance art is a complex cultural event which is a combination of several expressive elements organized as an entity. This basic assumption, according to the present writer, needs a careful theoretical background in its study and further it needs a multidisciplines approach by borrowing related-discipline approaches which are considered to enrich and improve the process of material analysis.

As we all know, the Sundanese wayang golek performance art is a people's performance art that cannot be separated from three main aspects, namely (1) the artist who performes it, in this case it refers to dalang (puppeteer) and his supporters (pengrawit - traditional musical instrumentalists, pesindèn - female traditional singer, wiraswara - male traditional singer and team creative); (2) the art work presented with its elements, and (3) the users and follower of the art or audiences (public). Therefore, to answer several questions regarding the dynamics of Sundanese wayang golek performance in the case study of wayang golek Panca Komara and wayang golek rampak dalang of Karawang, needs structuration analysis with the approach of Giddens' structuration theory (1984) namely 1) Agent, 2) Space, and 3) Time.

The agents in the Sundanese wayang golek performance are the performers such as dalang (puppeteer), nayaga (traditional musical instrumentalists), pesinden (female traditional singer), catrik (traditional musical instrument), and many other. The space of Sundanese wayang golek structure refers to a medium of puppetry art performers in expressing the work result of the puppetry to the audiences. The time is when, for an illustration, a country is a power holder based on the control of time and space. Modernity is a symptom of time and space separation. Globalization is an expansion and compaction of time and space. Without time and space, there will not be action. Thus, time and space must be integrated in social sciences.

The paradigm above shows that wayang golek performance considerably belongs to the old generations and not the young generations who recognize the wayang golek performance art as boring and not part of their life. Through structural transformations in innovation creativity and creative packaging in several elements of wayang golek performance, according to Suganda (2013:27), the answer is "yes, it can".

"Wayang golek harus dihadirkan kembali dalam format yang lebih modern dalam 
ranah seni kontemporer walaupun kecenderungannya hanya dalam lingkup bentuk pertunjukan atau deformasi figur yang berubah dari bentuk awal sebagai bangunan baru hasil kreativitas para seniman muda dalam meresponsnya, bukan pada hakikat jalan cerita dan nilai-nilai filosofisnya. Jika dikaitkan dengan teori perubahan struktur Giddens, maka ruang itu sangatlah logis karena struktur memainkan dan dimainkan oleh ruang dan waktu dimana dalam pertunjukan wayang golek Sunda sangatlah ketergantungan dengan ruang dan waktu bahkan hal tersebut akan banyak memberikan pengaruh terhadap eksistensi dan pertunjukan wayang golek tersebut".

Transformations in structuration logic happen through periodical transformations when the existing structures can no longer become the coordination principles of new evolving social practices.

As an illustration, Kresna (2012) in Suganda (2013:24) states:

"Munculnya lakon-lakon baru sampai saat sekarang ini beserta sajian perubahan lakon yang ditampilkan dalam pergelaran wayang kulit purwa ialah hal yang wajar sesuai dengan kebutuhan perkembangan zaman sejauh amanat yang terkandung dalam lakon tersebut dapat mengenai sasarannya".

Further he proposes that "Kreativitas tersebut perlu dihargai sejauh tak bertentangan dengan judul lakon maupun isi pokoknya yang mengandung kewajaran bagi dalang dalam menyusun cerita dan penyajiannya."

In accordance with the explanations and supported by the paradigm on the need of understanding the cause of transformations, the transformations in Sundanese wayang golek performance become a reality in society, relating to various factors both internal of dalang (puppeteer) and its supportive artists and external of other art groups along with general people. Suganda (2013:25) explains that:

"Dalam rentang ruang dan waktu kekinian, maka modifikasi sruktur wayang golek sangat memungkinkan untuk terjadi karena faktor-faktor dinamika sosial dan perkembangan zaman”.

"Dengan hukum-hukm ilmiah ini, manusia tidak saja dapat memahami apa yang menjadi dinamika dibalik gejala-gejala (fenomena), akan tetapi bahkan dapat meramalkan kearah gerak dinamika itu. Dengan kemampuan meramal, manusia bukan saja mampu menemukan cara-cara penyesuaian (adaptasi) namun bahkan melalui pengolahan (manipulasi) terhadap dinamika tersebut dapat mengendalikan fenomena kearah yang diinginkan" (Saini, 1989:511-52).

Along with the descriptions above, Sejalan dengan pemikiran tersebut, Alfian (1986: 38), explains that the development can mean adding or changing irrelevant matter to its age, in addition to continuing the existing process. Based on Sutrisno (2005:9), he states that transformations in a cultural level can be defined as follow:

"Suatu budaya akan ditinggalkan dan akhirnya hilang bila tidak ada kesinambungan dalam pewarisan. Pewarisan suatu budaya biasanya tidak lepas dari penyesuaian. 
Penyesuaian budaya sering kita dengar dengan sebutan tranformasi budaya. Adapun bentuk transformasi budaya secara garis besar ada tiga hal. Yaitu berbentuk ekstensi, konvensi, dan modifikasi. Ekstensi adalah situasi dimana suatu bentuk kebudayaan dibuat lebih luas dalam peruntukan, fungsi dan hal lainnya. Namun perluasan ini tidak mengubah bentuk asli dari kebudayaan tersebut. Adapun konvensi berarti mengubah suatu bentuk kebudayaan, tanpa menghilangkan fungsi dari kebudayaan yang ditransformasikan tersebut. Sedangkan modifikasi berarti mengubah suatu bentuk kebudayaan dengan cara mengurangi unsur yang dianggap sudah tidak relevan dengan jaman dan atau menambahkan unsur budaya luar pada budaya yang ditransformasi."

Sundanese wayang golek performance of Karawang in particular, is getting excluded in this globalization era. Today, wayang golek art needs attention from not only the government or performers but also all parties. Therefore, to balance it to contemporary conditions, the wayang golek art must be structurized but it still sticks to the main tradition. Without structurization balanced to innovation, the wayang golek art will be forgotten. Thus, the wayang golek performance reconstruction is a must so that the existence of wayang golek art can be accepted by general audiences (Suganda, 2013). The space and time provide by the government play a very important role in the preservation of wayang golek art. To perform wayang golek art is very expensive these days. This causes less possibility of people in many regions to hold wayang golek as an entertainment performance for ceremonial activities.

Tranformations of value system always happen. These transformations have two important elements in the process of cultural transformations, namely inculturation and acculturation processes. Both processes have a reciprocal relationship and changeably may become an obstacle or stimulant and experience continuation and end processes. Inculturation is a process of training of every cultural performer to adapt to on-going cultural transformations. In the conventional Sundanese wayang golek performance art, courage is necessary to apply transformation so that the inculturation is considered successful should the integration of tradition art and personal expression happens. Therefore, the values can assimilate dynamically in the performance.

The transformation process of Sundanese wayang golek performance art through cultural acculturation approach is a medium or area where two cultures meet and accept each other attached values. In this matter, collaboration happens in the performance packaging. In the performance of wayang golek Panca Komara Dalang Tjetjep Supriadi, the skillful capability in the play performance affects the wayang golek performance. The collaboration happens between the elements of the play, skillful capability as a teacher, religious figure, and dalang (puppeteer) influencing structural transformation of the performance.

To be successful, the process of acculturation requires several conditions, namely affinity, which is the acceptance of culture in applicable way; homogeneity, such as a new value combined due to the similarity of level and pattern of the culture; and function, such as a new value adapted only as a meaningless function or for packaging. These conditions accelerate the process of acculturation. The process of acculturation in the packaging of wayang golek 
Panca Komara performance to adjust the audiences' will is by reconstruction various elements which become the structure of wayang golek performance as an attraction of combining various powers which becomes a typical characteristic of the play performance in the wayang golek performance. The transformation in language and literature element is very dominant in the performance of wayang golek Panca Komara. Therefore, Tjetjep Supriadi becomes famous for his language and literature skill, dalang (puppeteer's voice) in particular.

The process of acculturation requires 'selection'. This selection refers to materials which are exactly appropriate to contexts and purposes of the packaging of wayang golek performance art. Furthermore, the transformations on the structure of wayang golek Panca Komara performance of Karawang are intentionally applied by Tjetjep Supriadi as the performer of conventional Sundanese wayang golek performance art in addressing various needs and transformations at the time. Tjetjep Supriadi plays as an agent of transformation who becomes the controller center of the transformation of the group of wayang golek Panca Komara of Karawang. He is assisted by several artists and practitioners as the performers of wayang golek puppetry art whom some of them become agents in its transformation process.

Paying attention to facts and reality of values conveyed in the Sundanese wayang golek performance, both as an entertainment and artistic meaning of performance medium, is possible for the Sundanese wayang golek to become a reliable medium of transformation for its audiences. To make a more interesting performance art from its original form (its tradition), needs re-packaging to form a new one. The process of transformation of wayang golek performance art is observable in the concenpt and pattern of management conducted by the creator of puppetry. Basically, packaging a performance art is a form of artist' work (creator) in arranging, choosing, and reconstructing the form to become the new one with new format and structure. The arranging, choosing, and reconstructing are the keys for a creator (artist) to express his/her idea and opinion.

Transformation is the most basic characteristic of life, to refuse transformation means culturally suicide (Saini KM, 2002). In a performance art, transformations may occur because of a demand due to humans' attitude. Humans manage life for their safety and wealth. However, these transformations cause reaction from life and humans must remanage. The most basic management belongs to the concept and level of systems including the systems of idea, attitude, and faculties. With the transformed systems, humans face and manage their life to be more adaptable with their safety and wealth as expected along with the continuation, which in this matter refers to the continuation of a performance art in the process of transformation from conventional to nonventional forms.

Regarding the process of transformation of the contemporary Sundanese wayang golek performance are, its process relates closely to the factor of need and also the internal factors of its art performers with the transformation from various angles such as the creative technique and pattern to make the packaging execution more innovative and interesting without disturbing the essence values of the puppetry. This can be achieved through the process of new translation of wayang golek art from conventional to non-conventional forms by packaging the structures and its varius elements of Sundanese wayang golek puppetry art 
to produce a better and highly marketable work art as public consumption in general, as it is applied by the group of wayang golek rampak 38 dalang 'Karawang Tandang” initiated by dalang (puppeteer) Darsa Wibiksana who is also the Head of Indonesia Puppetry Association of Karawang (Persatuan Pedalangan Indonesia (Pepadi) Karawang). Darsa Wibiksana is an agent of transformation to the performance of wayang golek Rampak dalang in Karawang. The art organization and bureaucracy have become his space and time to apply the transformations. Various transformations have been applied from the performers as the agents of transformations, performance equipments, scenes pattern, sabetan (wayang's movements), music, language and literature, time and space, stage arrangement, and costumes.

Rogers (1983:11) proposes that innovation is an idea, practice, or object which can be felt or considered as something new by an individual or other unit that adopts it. Regarding the creativity issue, Supriadi (2001:6) defines creativity as “one's ability to create something new, both idea or concrete work, which is relatively different from what has existed before." This statement is similar to Wallas' in Supriadi (2001:53-54) stating that there are four steps of creative process: preparation, incubation, illumination, and verification. Meanwhile, Rhodes divides the creativity dimensions into four elements, "The Four P's of Creativity." These four elements are person, process, press, and product. The dimensions relate to each other so that it is not possible to be separated from creative process, including those which are conducted by the wayang golek artist. Those concepts help in revealing the procedures and steps of the artists of wayang golek performance when packaging the performance aspects of wayang golek through the interpretation power and musical sensibility which they possess. Wayang golek as the result of transformation possesses technical demands such as time duration and contexts movements. This alternative way faces marketable value by presenting short performance of wayang golek. Dalang-dalang (the puppeteers) in the packaging performance can be included into the progressive and pragmatic categories because they try to apply transformations which are not in accordance with the conservative performance patterns and its transformations are based on the needs and audiences' appetite.

The creation of short wayang golek performance should not exclude other aesthetic elements such as the power of communication between audiences and puppetry art work, and its quality which must be upheld by the art performers. The aesthetic elements of puppetry art work must remains as an important consideration, even further performance art must reflect the cultural condition of where the art is. It is proven by the existence of Sundanese wayang golek performance which is different from the conventional one such as the performance of rampak dalang that may be categorized as a non-conventional wayang golek performance. The performance of wayang golek rampak dalang of Karawang with various packagings in its performance presents contemporary themes and it may become a momentum of the revival and creativity of Sundanese puppetry art to function and serve not only as an entertainment art but also as an attraction of tourism especially in Karawang and West Java in general.

\section{Conclusion}

The process of transformation in Sundanese wayang golek performance art of Karawang has happened. The effort to unite the performance concept between packaging and its 
environment has occurred as well. For instance, the performance of wayang golek Panca Komara of Karawang initiated by dalang (puppeteer) Tjetjep Supriadi considered conventional has transformed from its concept of old tradition which is considered more conventional. Therefore the existence of this group remains existed until today in Karawang. Moreover, the appearance of new style in the performance of wayang golek rampak dalang “Karawang Tandang” involving 38 dalang (puppeteers) serves a a new package with various contemporary elements existed so that it is categorized as a non-conventional wayang golek performance art. The transformations as a dynamic in Sundanese wayang golek performance art of Karawang occur through cultural transformations from conventional to non-conventional areas. The packaging of wayang golek performance makes its performance more attractive, short duration, and meaningful. Yet, it still shows its concept which is still attractive with its typical characteristics.

The structural transformations of the performance of wayang golek panca Komara and rampak dalang Karawang are a dynamic transformation through various elements in the performance structure such as 1) Performers, 2) Equipments, 3) Play, 4) Language and Literature, 5) Scenes Arrangement, 6) Sabet (wayang's movements), 7) Time and Settings of Performance, 8) Musical Element, 9) Stage Arrangement, and 10) Costumes.

This research reveals that the performance theory structure of both puppetry style of Panca Komara as a conventional form has transformed and rampak dalang as a non-conventional form always transforms. The wayang golek Panca Komara of Karawang with dalang (puppeteer) Tjetjep Supriadi applies the transformations through such as 1) observing old patterns, 2) imitating old patterns, 3) modifying old patterns, and 4) conducting repeatedly and always preserved as its typical characteristic. The wayang golek rampak dalang of Karawang applies 1) using and modifying old patterns, 2) discarding old patterns, 3) making new patterns, and 4) conducting varius transformations in its performance as its typical characteristic.

Thus, the transformations are very significant. The ten elements above have transformed variously. Of the ten elements transforming significantly are performers, equipments, time and settings, musical elements, sabet, and stage arrengemnet. The elements with insignificant transformations are language and literature, play, and scenes arrangement. The elements without transformations are wayang equipment, gamelan (traditional musical instruments), and language and literature which are preserved as the typical characteristics of Sundanese wayang golek. Therefore, should very important elements such as wayang equipment, gamelan (traditional musical instruments), and language and literature transform, the typical characteristics of Sundanese wayang golek will be no more.

\section{Recommendation}

The result of this research is that the existence of Sundanese wayang golek considering those conditions will be always able to answer various needs of modern age challenge because the Sundanese wayang golek is included in part of open tradition are which dynamically may transforms accordingly to time. The Sundanese wayang golek is built and reconstructed accordingly to balance the need and challenge of time so that it still can preserve, develop, be 
useful, appreciated and supported by its society. However, there are also several elements that may not be transformed to maintain its typical characteristics of Sundanese wayang golek. The functions of wayang golek as an entertainment, demand, and order develop to cultural asset for cultural tourism attraction which can be built by noticing various elements in the performance so that the performance can be more creative and innovative, balancing to the needs and demands of art for tourists attraction that is beneficial to the wealth of people and nation.

\section{Acknowledgement}

The research is financed by Ministry of Tourism and Creative Economy of Republic of Indonesia.

\section{References}

Alfian. (1986). Transformasi Sosial Budaya dalam Pembangunan Nasional. Jakarta: UI Press.

Brandon, J. R. (2003). Jejak-Jejak Seni Pertunjukan di Asia Tenggara. Terj. R.M. Soedarsono. Bandung: P4ST.UPI.

Djelantik, A. A. M. (1990). Pengantar Ilmu Estetika Jilid I-Estetika Instrumental. STSI Denpasar.

Folley, K. (1979). The Sundaneseawaii: Wayang Golek: The Road Puppet Theatre of West Java. Hawaii: University of Hawaii.

Giddens, A. (1984). The Constitution of Society. Teori Struktur untuk Analisis Sosial, diterjemahkan oleh Adi Loka Sujono. (1995). Yogyakarta: Pedati.

Giddens, A. (2010). Teori Strukturasi, Dasar-Dasar Pembentukan Srtuktur Sosial Masyarakat. Yogyakarta: Pustaka Pelajar.

Herbert, M. (2002). Voice of the Puppet Masters, The Wayang Golek Theater of Indonesia. Jakarta: Yayasan Lontar.

Kasidi, H. (1996). Antara Tradisi dan Inovasi Jagad Pewayangan. Makalah pada Rapat Konsultasi Litbang Wayang, 16-17 November 1996, Jakarta: Senawangi.

Kayam, U. (1981). Seni, Tradisi, Masyarakat. Jakarta: Penerbit Sinar Harapan.

Kotler, P., \& Susanto, A. B. (2001). Managemen Pemasaran. Terjemahan Hendra Teguh, Ronny A. Rusli dan Benyamin Molan, Jakarta: Milenium, Prenhallindo.

Lisday, J. (1991). Klasik, Kitch, Kontemporer: Sebuah Study tentang Seni Pertunjukan Jawa. Yogyakarta: Gadjah Mada University Prees.

Murgianto, S. (2014). Tradisi dan Inovasi Beberapa Masalah Tari di Indonesia. Wedatama Widya Sastra.

Nalan, A. S. (2012). Gaya Mendalang Murid-Murid Asep Sunandar Sunarya (Studi Fenomenologi). Disertasi. Bandung: Program Pascasarjana Universitas Padjajaran. 
Ratna, N. K. (2010). Metodologi Penelitian Kajian Budaya dan Ilmu Sosial Humaniora pada umumnya. Yogyakarta: Pustaka Pelajar.

Roger, S., \& Everett, M. (1983). Diffusion of Innovations: Third edition, Tenth printing. New York. The Free Press.

Rosidi, A. (2000). Ensiklopedi Sunda: Alam, Manusia, dan Budaya. Jakarta: Pustaka Jaya.

Rustama, T. K. (2004). Inovasi Dalam Pertunjukan Wayang Golek Sunda. Disertasi. Yogyakarta. Program Pascasarjana Universitas Gadjah Mada.

Saini, K. M. (1981). Beberapa Gagasan Teater. Yogyakarta: CV. Nur Cahaya.

Saini, K. M. (2002). Kaleidoskop Teater Indonesia. Bandung: STSI Press.

Salmun, M. A. (1961). Padalangan. Jakarta: Balai Pustaka.

Sedyawati, E. (1981). Pertumbuhan Seni Pertunjukan. Jakarta: Sinar Harapan.

Soedarsono, R. M. (2002). Seni Pertunjukan Indonesia di Era Globalisasi. Yogyakarta: Gadjah Mada Press.

Soepandi, A. (1984). Pergelaran Wayang Golek Purwa Gaya Priangan. Pustaka Buana Bandung.

Solichin. (2004). Wayang Karya Agung Budaya Dunia. Senawangi: Jakarta

Suganda, D. (2013). Struktur Wayang Golek dalam ruang dan waktu; Makalah disampaikan pada acara seminar sehari menyongsong Wayang World Puppet Carnival 2013, bertempat di Aula PSBJ Fakultas Ilmu Budaya Universitas Padjajaran, Jatinagor Kab. Sumedang, Kamis tanggal 13 Juni.

Sumardjo, J. (2000). Filsafat Seni. Bandung: Institut Teknologi Bandung.

Supriadi, D. (2001). Kreativitas, Kebudayaan \& Perkembangan Iptek. Cetakan kelima.Bandung: CV.Alfabeta.

Suryana, J. (2002). Wayang Golek Sunda: Kajian Estetika Rupa Tokoh Golek. Bandung. PT.Kiblat Buku Utama.

Suseno, F. M. (1991). Wayang dan Panggilan Manusia. Jakarta: PT. Gramedia Pustaka Utama.

\section{Copyright Disclaimer}

Copyright for this article is retained by the author(s), with first publication rights granted to the journal.

This is an open-access article distributed under the terms and conditions of the Creative Commons Attribution license (http://creativecommons.org/licenses/by/3.0/). 